Дніпропетровський національний університет імені Олеся Гончара Природний заповідник «Дніпровсько-Орільський»

\title{
ЕКОМОРФІЧНА СТРУКТУРА ФІТОЦЕНОЗІВ НА АРЕНІ р. ДНІПРО (В МЕЖАХ ПРИРОДНОГО ЗАПОВІДНИКА «ДНІПРОВСЬКО-ОРІЛЬСЬКИЙ»)
}

Проведено екоморфічний аналіз фітоценозів на арені р. Дніпро в межах природного заповідника «Дніпровсько-Орільський». Оцінено екологічну специфіку фітоценозів, що є основою для розробки екологічно обгрунтованого їх збереження. Визначено, що у фітоценозах значну частину складають багаторічники. Проаналізовано ценоморфічну, трофоморфічну та гігроморфічну структуру фітоценозів. Різноманітні шляхи рознесення насіння призводять до формування значного потенціалу дистрибуції рослин у межах та за межами досліджуваного полігону.

Ключові слова: ценоморф, фітоценози, біогеоценози, фітоіндикація, трофоморф, гігротоп, екоморф.

\author{
Н. Г. Гудым, Д. С. Ганжа
}

Днепропетровский нащиональный университет имени Олеся Гончара Природный заповедник "Днепровско-Орельский»

\section{ЭКОМОРФИЧЕСКАЯ СТРУКТУРА ФИТОЦЕНОЗОВ НА АРЕНЕ р. ДНЕПР (В ПРЕДЕЛАХ ПРИРОДНОГО ЗАПОВЕДНИКА «ДНЕПРОВСКО-ОРЕЛЬСКИЙ»)}

Проведен экоморфический анализ фитоценозов на арене р. Днепр в пределах природного заповедника «Днепровско-Орельский». Оценена экологическая специфика сообществ фитоценозов, что является основой для разработки экологически обоснованного их сохранения. Определено, что в фитоценозах значительную часть составляют многолетники. Проанализированы ценоморфическая, трофоморфическая и гигроморфическая структуры фитоценозов. Различные пути разнесения семян приводят к формированию значительного потенциала дистрибуции растений в пределах и за пределами исследуемого полигона.

Ключевые слова: ценоморф, фитоценозы, биогеоценозы, фитоиндикация, трофоморф, гигротоп, экоморф.

\section{N.G. Gudym, D.S. Ganzha \\ Oles Honchar Dnipropetrovsk National University. Nature reserve "Dneprovsko-Orylskiy», Ukraine \\ ECOMORPH STRUCTURE OF PHYTOCENOSIS \\ ON THE ARENA OF THE DNIPRO RIVER (WITH IN DNIPRO-ORELSKY NATURAL RESERVE)}

It was conducted an ecomorph analysis of plant communities in the arena of the Dnipro river within the Nature Reserve «Dnieper-Orilsky». Vegetation is an essential component of biogeocoenosis, which provides vital activity for other biotic components. Therefore, changes in vegetation under the influence of various environmental factors affect the state biogeocoenosis in general. Environmental analysis of plant communities allows qualitative assessment of plant communities and their comparison by composition of coenomorph, klimamorph, heliomorf, termomorf, trophomorf and hygromorf. The purpose of this study is analyzing the ecomorph structure of phytocenosis communities by the system of plants ecomorph of $\mathrm{O}$. L. Bellgard (1950) in the arena of the Dnipro river.

(C) Н. Г. Гудим, Д. С. Ганжа, 2016 
Researches were conducted from April to November 2015 in the natural reserve «Dnipro -Orilskyy.» It was found 140 species of plants on the investigated ground. We have laid the 24 sample plots with the size of 10 to $10 \mathrm{~m} 2$ in three single repetition: psammophilous step, dune lowering (4 points); black maple shrubs (4 points) artificial pine plantations in the arena (this and all other habitats $\mathbf{- 3}$ points), deciduous forest plantations, meadow (two points in the floodplain of Protochna river and one in Orlov ravine), swamps. Plant ekomorphes are presented by $O$. L. Bellgard (1950) and V. V. Tarasov (2012). The largest part of the structure coenomorph is taken by stepants and silvants. There are all types of coenomorph in almost every plant community, coenomorph structure varies but within some biogeocenoses and it is represented by several coenomorphes. We found that stepants occupy the largest share in phytocenosis communities. The largest portion of the trophpmorph structure is occupied by oligotroph followed by mezatroph, oliho mezatroph and megatroph, smallest part is taken by alkatroph and mezomegotroph. Trophic index of edaphotope by ekomorph of $O$. L. Bellgard (1950) indicates that according to this indicator it is observed the variability from poor marginal soils that are conducive to oligotroph to the rich fertile soil, favorable for megatroph. Biogeocoenosis are characterized by large range of hygromorph structures that vary greatly. The largest portion of the hygromorph structure is occupied by mezokserophytes and kseromezophytes, kserophytes. The smallest share is taken by hydromezophytes, mezohygrophytes, and hygrophytes. Index of humidity regime of edaphotope by ekomorph of $O$. $L$. Bellgard (1950) indicates that according to this indicator it is observed points out that this indicator observed variability from the arid conditions that are favorable for kserophytes and mezokserophytes to wet conditions that are favorable to mezohygrophytes. Pollinohoric structure emphasizes features of pollination within phytocenosis communities. The predominant type of pollination is anemophilia which is pollination by wind. Pollinohoric structure points to the important role of wind in the dusty plant communities. Diasporochoria reflects the types of dissemination - ways of resettlement of plants diaspora. The analysis revealed that diaspochoria occurs in all types among plants and vegetation of investigated landfill. There are three main types: Bal, Anch, Epz. It was estimated the environmental specific of phytocenosis communities, which is the basis for the development of their environmentally sound storage.It was determined that significant part of the phytocenosis communities is taken by perennials. Coenomorph, trophomorf and hygromorf structure of plant communities was analyzed. Trophotope of the landfill is moderately rich; hygrotope is a little fresh; coenomorph is a plain with forest vegetation. Various ways of resettlement of the seed lead to the formation of significant potential for distribution of plants within and outside the studied site in the arena of the Dnipro river. ekomorf.

Keywords: tsenomorf, phytocenoses, biogeocoenoses, phytoindication, trofomorf, gigrotop,

Рослинність $€$ найважливішим компонентом біогеоценозу, що забезпечує життєдіяльність інших біотичних компонентів. Тому зміни рослинності під дією різних факторів зовнішнього середовища впливають на стан біогеоценозу в цілому, внаслідок цього можуть використовуватися в якості діагностичних ознак [14]. Перевага використання рослин полягає в тому, що вони нерухомі [10]. Рослинність формує елемент навколишнього середовища в комплексі з іншими елементами, тому є хорошим індикатором змін екологічних умов.

Фітоіндикація має певні переваги порівняно із застосуванням прямих фізичних і хімічних методів оцінки екологічного стану середовища і може здійснюватися за реакцією видів рослин, які найбільш чутливі до полютантів, або за накопиченням шкідливих речовин в тілі рослин $[6 ; 9 ; 13]$. Властивостями фітоіндикаціоного методу є доступність, простота та ефективність [4; 5; 6 14]. Роздільна здатність фітоіндикаційних методів досить висока, сфери прикладання та виконання різних практичних завдань найрізноманітніші: від біоіндикації антропогенного впливу до оцінки глобальних змін ландшафтів і екосистем [10].

Екологічний аналіз фітоценозів на основі схеми екоморф за О. Л. Бельгардом дозволяє розкрити взаємозв'язки рослинних організмів і середовища, з'ясувати 
ступінь пристосування фітокомпонентів до найважливіших елементів екосистеми [11]. Система екоморф рослин О. Л. Бельгарда розроблена в 1950 році та використовується до теперішнього часу. Вона дозволяє здійснювати якісну оцінку рослинних угруповань та їх порівняння між собою за складом ценоморф, клімаморф, геліоморф, термоморф, трофоморф і гігроморф [1;2; 13].

Мета даного дослідження - провести аналіз екоморфічної структури фітоценозів за системою екоморф рослин О. Л. Бельгарда на арені р. Дніпро в межах природного заповідника «Дніпровсько-Орільський».

Матеріали та методи досліджень. Дослідження проведені з квітня по листопад 2015 р. у природному заповіднику «Дніпровсько-Орільський». Нами було закладено 24 пробні площі розміром $10 \times 10 \mathrm{~m}^{2}$ у триразовій повторності у таких типах біогеоценозів: псамофільний степ, проміждюнне пониження (4 точки); чорнокленові чагарники (4 точки), штучне насадження сосни на арені (тут та всі інші біотопи - по 3 точки), широколистяне природне лісове насадження, луг (дві точки у заплаві р. Проточ та одна - у тальвезі балки Орлова), болото. Загальна площа дослідженого полігону становить 930 га [7]. У кожному квадраті зроблено опис рослинності з оцінкою проективного покриття з лагом $10 \%$ [3]. Екоморфи рослин наведено за О. Л. Бельгардом [1] і В. В. Тарасовим [15]. Ценоморфи представлено степантами, полюдантами, пратантами, псамофітами, сільвантами і рудерантами. Гігроморфи представлені ксерофітами (рівень вологості 1), мезоксерофітами (рівень вологості 2), ксеромезофітами (рівень вологості 3), мезофітами (рівень вологості 4), гігромезофітами (рівень вологості 5), мезогігрофітами (рівень вологості 6), гігрофітами (рівень вологості 7). Рівень вологості по гігроморфічній структуpi (Hygr) оцінено як [17]:

$$
\text { Hygr }=\frac{\sum_{i=1}^{i=N}\left(i \times P_{i}\right)}{100},
$$

де $\mathrm{i}$ - рівень вологості; $P_{i}$ - проективне покриття рослин відповідної гігроморфи.

Трофоморфи представлено оліготрофами (рівень трофності 1), мезотрофами (рівень трофності 2) і мегатрофами (рівень трофності 3). Рівень трофності за трофоморфічною структурою (Troph_B) оцінено як:

$$
\text { Troph_B }=\frac{\sum_{j=1}^{j=N}\left(j \times p_{j}\right)}{100},
$$

де $j$ - рівень трофності; $p_{j}$ - проективне покриття рослин відповідної трофоморфи.

Структуру діаспорохорії рослин наведено за В. В. Тарасовим [15]: Ach - автохори; Hdch. - гідрохори; Anch. - анемохори; Myrm. - мирмекохори; Bar. - барохори; Perv. - первольвенти; Bal. - балісти; SynZ. - синзоохори; EpZ. - епізоохори; EndZ. - ендозоохори.

Статистичні розрахунки проведені за допомогою програми Statistica 7,0 і програмної оболонки Project R «R: A Language and Environment for Statistical Computing» (http://www,R-project,org/).

Результати та їх обговорення. На досліджуваному полігоні знайдено 140 видів рослин. Ценоморфічну структуру рослинності у досліджених біогеоценозах представлено в табл. 1. Аналіз даних, наведених у таблиці, дозволяє розкрити взаємозв'язки рослинних організмів і середовища, з'ясувати ступінь пристосування фітокомпонентів до найважливіших елементів екосистеми. Ценоморфи адаптації рослин до фітоценозу та біогеоценозу в цілому, у тому числі до типу субстрату або середовища існування $[1 ; 11]$.

У межах дослідженого полігону ценоморфічну структуру рослинності представляють: полюданти, пратанти, псамофіти, рудеранти, сільванти та степанти. Найбільшу частину в структурі ценоморф займають степанти і сільванти. Майже в кожному фітоценозі зустрічаються усі типи ценоморф, але між деякими біогеоценозами структура ценоморф сильно змінюється і представлена кількома цено- 
морфами. За ценоморфічними особливостями досліджені фітоценози можна віднести до моноценозів, амфіценозів та псевдомоноценозів.

До лісових моноценозів належать: в'язо-осокорова діброва, діброва (пробна площа № 15), насадження сосни (пробна площа № 18). До псевдомоноценозів можна віднести такі: діброви поблизу болота (№ 16, 17), чорнокленова діброва, лугові угруповання, чорнокленові угруповання. Амфіценози представлені так (більше 20 \% домішок інших ценоморф): діброва поблизу болота (№ 20), луки, насадження сосни, псамофільний степ, нижня частина проміждюного пониззя та верхня частина дюни, чорнокленові угруповання.

Таблиия 1

\section{Ценоморфічна структура рослинних угруповань (у \% від загального проективного покриття)}

\begin{tabular}{|c|c|c|c|c|c|c|c|}
\hline № & Рослинні асоціації & Pal & $\operatorname{Pr}$ & Ps & $\mathrm{Ru}$ & Sil & St \\
\hline 1 & $\begin{array}{l}\text { Лука з куничником наземним та тонконогом лучним } \\
\text { Calamagrostietum (epigeios) poosum (pratensis) }\end{array}$ & 11,21 & 57,76 & 0,86 & 13,79 & 5,17 & 11,21 \\
\hline 2 & $\begin{array}{l}\text { Чорнокленова діброва з грястицею Acereto (tataricum) - } \\
\text { quercusetum (roburi) Dactyliosum (glomerata) }\end{array}$ & - & - & - & 26,16 & 68,02 & 5,81 \\
\hline 3 & $\begin{array}{l}\text { Насадження сосни з куничником наземним Pinetum } \\
\text { (sylvestris) calamagrostiosum (epigeios) }\end{array}$ & - & 38,84 & 1,65 & 8,26 & 46,28 & 4,96 \\
\hline 4 & $\begin{array}{l}\text { Лука із пирієм повзучим та осотом польовим Elytrigietum } \\
\text { (repens) cirsiosum (arvense) }\end{array}$ & - & 56,49 & - & 17,56 & 12,21 & 13,74 \\
\hline 5 & $\begin{array}{l}\text { Насадження сосни із стоколосом безостим Pinetum } \\
\text { (sylvestris) Bromopsiosum (inermis) }\end{array}$ & - & - & 22,39 & 2,99 & 52,99 & 21,64 \\
\hline 6 & $\begin{array}{l}\text { Псамофільний степ, жито дике з кострицею Беккера } \\
\text { Secaletum (sylvestre) festucosum (beckeri) }\end{array}$ & - & 5,43 & 56,59 & - & 16,28 & 21,71 \\
\hline 7 & $\begin{array}{l}\text { Псамофільний степ, жито дике з жабрицею звивистою } \\
\text { Secaletum (sylvestre) seseliosum (tortuosum) }\end{array}$ & - & - & 82,35 & - & 1,47 & 16,18 \\
\hline 8 & $\begin{array}{l}\text { Псамофільний степ, житняк пухнастоквітковий з кострицею } \\
\text { Беккера Agropyretum (dasyanthum) festucosum (beckeri) }\end{array}$ & - & 7,75 & 74,42 & - & - & 17,83 \\
\hline 9 & $\begin{array}{l}\text { Псамофільний степ, анізанта покрівельна з осокою ранньою } \\
\text { Anisanthosum (tectorum) carexosum (praecox) }\end{array}$ & - & 27,59 & 35,34 & - & 0,86 & 36,21 \\
\hline 10 & $\begin{array}{l}\text { Татарсько-кленова асоціація з житом диким Aceretum } \\
\text { (tataricum) secaleosum (sylvestre) }\end{array}$ & - & - & 27,66 & - & 55,32 & 17,02 \\
\hline 11 & $\begin{array}{l}\text { Татарсько-кленова асоціація з житняком пухнастоквітковим } \\
\text { Aceretum (tataricum) agropyrosum (dasyanthum) }\end{array}$ & - & 4,40 & 28,57 & 1,10 & 54,95 & 10,99 \\
\hline 12 & \begin{tabular}{|l|} 
Татарсько-кленова асоціація з жостером проносним \\
Aceretum (tataricum) rhamnosum (cathartica) \\
\end{tabular} & - & 2,24 & 35,82 & - & 46,27 & 15,67 \\
\hline 13 & $\begin{array}{l}\text { Псамофільний степ, келерія піскова з кострицею Беккера } \\
\text { Koelerietum (sabuletorum) festucosum (beckeri) }\end{array}$ & - & 14,10 & 41,03 & 6,41 & - & 38,46 \\
\hline 14 & $\begin{array}{l}\text { Псамофільий степ, костриця Беккера з житом диким } \\
\text { Festucetum (beckeri) secaleosum (sylvestre) }\end{array}$ & - & - & 56,00 & 4,00 & - & 40,00 \\
\hline 15 & \begin{tabular}{|l|} 
В'язова діброва з ожиною \\
Ulmeto (laevis) - quercusetum (roburi) rubosum (caesiuci) \\
\end{tabular} & 0,70 & - & - & 6,99 & 91,61 & 0,70 \\
\hline 16 & $\begin{array}{l}\text { Осокір чорний з осокою гострою Populetum (nigrae) } \\
\text { carexosum (acuta) }\end{array}$ & 6,54 & - & - & 16,99 & 76,47 & - \\
\hline 17 & $\begin{array}{l}\text { Вербняк з підмареником чіпким Salixetum (alba) galiosum } \\
\text { (aparine) }\end{array}$ & - & - & - & 12,75 & 81,37 & 5,88 \\
\hline 18 & $\begin{array}{l}\text { Насадження сосни з в'язом та бугилою Ulmeto (laevis) - } \\
\text { Pinetum (sylvestris) Anthriscosum (longirostris) }\end{array}$ & - & - & - & 1,30 & 92,21 & 6,49 \\
\hline 19 & $\begin{array}{l}\text { В'язо-осокір з розхідником Ulmeto (laevis) - Populetum } \\
\text { (nigrae) glechomosum (hederacea) }\end{array}$ & - & - & - & - & 96,97 & 3,03 \\
\hline 20 & $\begin{array}{l}\text { Болото з живокістом лікарським та перстачем повзучим } \\
\text { Symphyetum (officinale) potentilosum (reptans) }\end{array}$ & 22,39 & 43,28 & - & 8,96 & 16,42 & 8,96 \\
\hline 21 & $\begin{array}{l}\begin{array}{l}\text { Лука з кострицею валіською та солонечником Festuetum } \\
\text { (valesiaca) galatelosum (novopokrovskii) }\end{array} \\
\end{array}$ & 5,33 & 66,00 & - & 4,00 & 1,33 & 23,33 \\
\hline 22 & $\begin{array}{l}\text { Псамофільний степ, костриця Беккера з житом диким } \\
\text { Festucetum (beckeri) Secaleosum (sylvestre) }\end{array}$ & - & - & 55,56 & - & 11,11 & 33,33 \\
\hline 23 & $\begin{array}{l}\text { Псамофільний степ, келерія піскова з кострицею Беккера } \\
\text { Koelerietum (sabuletorum) festucosum (beckeri) }\end{array}$ & - & - & 24,53 & - & 18,87 & 56,60 \\
\hline 24 & $\begin{array}{l}\text { Сосна звичайна з кленом татарським Pinetum (sylvestris) } \\
\text { acerosum (tataricum) }\end{array}$ & - & 3,57 & 12,50 & - & 78,57 & 5,36 \\
\hline
\end{tabular}


Степанти мають найбільше значення в угрупованнях псамофітного степу. Частка степантів у псамофітних угрупованнях, які розміщені у нижній частині проміждюного пониззя, варіює в діапазоні 21,71-56,60 \%, при розміщенні у верхній частині дюн цей показник становить 16,18-38,46 \%. Частка псамофітів варіює в діапазоні 55,56-82,35 \% у нижній частині проміждюного пониззя. Найбільше значення в угрупованнях дібров займають сільванити, їх частка складає у діапазоні 68,02-96,97 \%. Також у діброві значна частка належить рудерантам 6,9926,16 \%, що вказує на наявність антропогенного впливу на досліджені фітоценози. Найбільша частка протантів і полюдантів припадає на фітоценози луків (варіабельність у діапазоні 57,76-66,00 \%) та дібров поблизу боліт (6,54-22,39 \%). Виявлене співвідношення екоморф вказує на те, що степанти і сільванти складають основну частину рослинного покриву.

Трофічна структура рослинності дослідженого полігону представляє собою: оліготрофи, олігомезотрофи, мезотрофи, мезомегатрофи, мегатрофи, алькалітрофи (табл. 2).

Таблиия 2

Трофоморфічна структура рослинності пробних площ

\begin{tabular}{|c|c|c|c|c|c|c|c|}
\hline \multirow{2}{*}{ № ПП } & \multicolumn{6}{|c|}{ Трофоморфи, \% від проективного покриття } & \multirow{2}{*}{ Індекс трофності } \\
\hline & OgTr & OlgMsTr & $\mathrm{MsTr}$ & $\operatorname{MsMgTr}$ & $\mathrm{MgTr}$ & AlkTr & \\
\hline 1 & 13,79 & 7,76 & 52,59 & - & 23,28 & 2,59 & 2,13 \\
\hline 2 & 8,72 & - & 58,72 & - & 32,56 & - & 2,24 \\
\hline 3 & 52,07 & 2,48 & 26,45 & - & 19,01 & - & 1,66 \\
\hline 4 & 19,08 & 19,85 & 45,04 & - & 16,03 & - & 1,87 \\
\hline 5 & 48,51 & 2,24 & 37,31 & - & 11,94 & - & 1,62 \\
\hline 6 & 79,07 & 1,55 & 6,98 & - & 8,53 & 3,88 & 1,36 \\
\hline 7 & 98,53 & - & - & - & 1,47 & - & 1,03 \\
\hline 8 & 93,02 & 6,20 & 0,78 & - & - & - & 1,04 \\
\hline 9 & 62,93 & 5,17 & 0,86 & - & 31,03 & - & 1,66 \\
\hline 10 & 26,60 & 3,19 & 61,70 & - & 8,51 & - & 1,80 \\
\hline 11 & 38,46 & 1,10 & 59,34 & - & 1,10 & - & 1,62 \\
\hline 12 & 47,01 & 2,24 & 50,75 & - & - & - & 1,52 \\
\hline 13 & 71,79 & 6,41 & 15,38 & - & - & 6,41 & 1,38 \\
\hline 14 & 72,00 & 9,33 & 18,67 & - & - & - & 1,23 \\
\hline 15 & 12,59 & 9,09 & 32,87 & - & 45,45 & - & 2,28 \\
\hline 16 & 1,96 & 6,54 & 76,47 & - & 15,03 & - & 2,10 \\
\hline 17 & 19,61 & - & 53,92 & - & 26,47 & - & 2,07 \\
\hline 18 & 16,88 & - & 81,82 & - & 1,30 & - & 1,84 \\
\hline 19 & 7,58 & - & 53,79 & - & 38,64 & - & 2,31 \\
\hline 20 & - & 17,91 & 70,15 & - & 11,94 & - & 2,03 \\
\hline 21 & 4,00 & 4,67 & 64,67 & 0,67 & 22,00 & 4,00 & 2,24 \\
\hline 22 & 91,11 & 8,89 & - & - & - & - & 1,04 \\
\hline 23 & 88,68 & 9,43 & 1,89 & - & - & - & 1,07 \\
\hline 24 & 66,07 & 3,57 & 28,57 & - & 1,79 & - & 1,34 \\
\hline
\end{tabular}

Вказані трофоморфи представлені майже у кожному фітоценозі та роль в угрупованні значно змінюється між біогеоценозами. Найбільшу частину у трофоморфній структурі займають оліготрофи. Дещо менше значення в угрупованні мають мезотрофи, олігомезотрофи та мегатрофи. Найменьша частка в угрупованні у алькатрофів та мезамегатрофів.

Індекс трофності едафотопу за екоморфами О. Л. Бельгарда [1] вказує на те, що за цим показником спостерігається варіабельність від бідних малородючих 
грунтів, які сприятливі для оліготрофів, до багатих родючих грунтів, сприятливих для мегатрофів. Найменша трофність едафотопу характерна для псамофільного степу (індекс 1,04), а найбільша - для в'язо-осокорової діброви (індекс 2,31).

Гігроморфічна структура рослинності дослідженого полігону представлена широким діапазоном: ксерофітами, мезоксерафітами, ксеромезофітами, мезофітами, гідромезофітами, мезогігрофітами, гігрофітами (табл. 3).

Гігроморфічна структура рослинності пробних площ

Таблиия 3

\begin{tabular}{|c|c|c|c|c|c|c|c|c|}
\hline \multirow{2}{*}{ № пробної ділянки } & \multicolumn{7}{|c|}{ Гігроморфи, \% від проективного покриття } & \multirow{2}{*}{ Індекс вологості } \\
\hline & Ks & MsKs & KsMs & Ms & $\mathrm{HgMs}$ & $\mathrm{MsHg}$ & $\mathrm{Hg}$ & \\
\hline 1 & - & 20,69 & 22,41 & 40,52 & 5,17 & 0,86 & 10,34 & 3,74 \\
\hline 2 & - & 25,00 & 23,26 & 40,12 & 11,63 & - & - & 3,38 \\
\hline 3 & 24,79 & 23,97 & 23,14 & 28,10 & - & - & - & 2,55 \\
\hline 4 & - & 31,30 & 43,51 & 24,43 & 0,76 & - & - & 2,95 \\
\hline 5 & 37,31 & 17,16 & 34,33 & 11,19 & - & - & - & 2,19 \\
\hline 6 & 52,71 & 37,21 & 5,43 & 4,65 & - & - & - & 1,62 \\
\hline 7 & 14,71 & 83,82 & 1,47 & - & - & - & - & 1,87 \\
\hline 8 & 47,29 & 44,96 & 3,88 & 3,88 & - & - & - & 1,64 \\
\hline 9 & 12,93 & 28,45 & 31,03 & 27,59 & - & - & - & 2,73 \\
\hline 10 & 15,96 & 18,09 & 58,51 & 7,45 & - & - & - & 2,57 \\
\hline 11 & 12,09 & 19,78 & 56,04 & 12,09 & - & - & - & 2,68 \\
\hline 12 & 14,93 & 20,90 & 41,04 & 23,13 & - & - & - & 2,72 \\
\hline 13 & 39,74 & 41,03 & 6,41 & 12,82 & - & - & - & 1,92 \\
\hline 14 & 33,33 & 56,00 & 10,67 & - & - & - & - & 1,77 \\
\hline 15 & - & 27,97 & 31,47 & 39,86 & - & 0,70 & - & 3,14 \\
\hline 16 & - & 1,31 & 29,41 & 58,17 & 4,58 & 6,54 & - & 3,86 \\
\hline 17 & - & - & 31,37 & 65,69 & 2,94 & - & - & 3,72 \\
\hline 18 & 12,99 & 14,29 & 41,56 & 31,17 & - & - & - & 2,91 \\
\hline 19 & - & 30,30 & 27,27 & 42,42 & - & - & - & 3,12 \\
\hline 20 & - & 7,46 & 32,84 & 14,93 & 22,39 & 22,39 & - & 4,19 \\
\hline 21 & 20 & 20,67 & 19,33 & 33,33 & 4,67 & - & 2,00 & 2,90 \\
\hline 22 & 55,56 & 44,44 & - & - & - & - & - & 1,44 \\
\hline 23 & 33,96 & 66,04 & - & - & - & - & - & 1,66 \\
\hline 24 & 44,64 & 17,86 & 28,57 & 8,93 & - & - & - & 2,02 \\
\hline
\end{tabular}

Біогеоценози характеризуються великим спектром гігроморфічної структури та сильно змінюються між собою. Найбільшу частку у структурі гігроморф складають мезоксерофіти та ксеромезофіти, ксерофіти. Найменшу частку - гігромезофіти, мезогігрофіти, гігрофіти. Нами встановлено, що найбільш посушливими $\epsilon$ грунти піщаного степу, а найбільш вологими - грунти дібров поблизу боліт. Індекс режиму вологості едафотопу за екоморфами О. Л. Бельгарда [1] вказує на те, що за цим показником спостерігається варіабельність від засушливих умов, які сприятливі для ксерофітів та мезоксерофітів, до найвологіших умов, які сприятливі для мезогігрофітів, гігрофітів.

Найбільш сухі умови характерні для псамофільного степу (індекс 1,44), а найбільш вологі - для діброви поблизу болота (індекс 4,19). Луки, насадження сосни, чорнокленовні угруповання перебувають на одному рівні режиму вологості (варіабельність індексу 2,55-2,95 - вологі умови, сприятливі для ксеромезофітів).

Нами було розглянуто основні типи опилення і розповсюдження плодів та насіння рослинності на дослідженому полігоні (табл. 4). 
Структура полленохор та діаспорохор*

\begin{tabular}{|c|c|c|c|c|c|c|c|c|c|c|c|c|}
\hline \multirow{2}{*}{ № } & $\begin{array}{c}\text { Полленохори, \% } \\
\text { від проективного } \\
\text { покриття }\end{array}$ & \multicolumn{10}{|c|}{ Діаспорохори, \% від проективного покриття } \\
\cline { 2 - 20 } & Anрh & Ent & Ach & Anch & Bal & Bar & Endz & Epz & Hdch & Myrm & Perv & Synz \\
\hline 1 & 34,48 & 65,52 & 2,59 & 47,41 & 39,66 & 2,59 & 0,86 & - & 6,90 & - & - & - \\
\hline 2 & 11,63 & 88,37 & 8,72 & 9,30 & 15,12 & 8,72 & 24,42 & 5,81 & 1,74 & 8,72 & - & 17,44 \\
\hline 3 & 50,41 & 49,59 & 0,83 & 48,76 & 23,14 & - & 19,01 & 1,65 & 4,13 & - & 1,65 & 0,83 \\
\hline 4 & 35,11 & 64,89 & - & 36,64 & 47,33 & 0,76 & 7,63 & 7,63 & - & - & - & - \\
\hline 5 & 56,72 & 43,28 & 5,97 & 26,87 & 51,49 & - & 7,46 & - & 3,73 & 3,73 & - & 0,75 \\
\hline 6 & 74,42 & 25,58 & 2,33 & 6,98 & 58,14 & - & 4,65 & 19,38 & 0,78 & - & 2,33 & 5,43 \\
\hline 7 & 82,35 & 17,65 & - & 1,47 & 32,35 & - & - & 51,47 & - & - & 14,71 & - \\
\hline 8 & 85,27 & 14,73 & 3,88 & 2,33 & 82,17 & - & - & 11,63 & - & - & - & - \\
\hline 9 & 79,31 & 20,69 & 4,31 & 0,86 & 58,62 & - & 1,72 & 34,48 & - & - & - & - \\
\hline 10 & 35,11 & 64,89 & - & 54,26 & 24,47 & - & 9,57 & 10,64 & - & 1,06 & - & - \\
\hline 11 & 36,26 & 63,74 & - & 50,55 & 36,26 & - & 8,79 & 1,10 & 3,30 & - & - & - \\
\hline 12 & 49,25 & 50,75 & - & 29,85 & 35,07 & 2,24 & 19,40 & 11,19 & - & 2,24 & - & - \\
\hline 13 & 84,62 & 15,38 & 6,41 & - & 89,74 & - & - & 3,85 & - & - & - & - \\
\hline 14 & 70,67 & 29,33 & 8,00 & 4,00 & 64,00 & - & - & 20 & - & - & 4,00 & - \\
\hline 15 & 10,49 & 89,51 & - & 17,48 & 18,18 & 6,99 & 22,38 & 6,99 & - & - & - & 27,97 \\
\hline 16 & 66,67 & 33,33 & - & 58,82 & 10,46 & 6,54 & 1,96 & 13,73 & 7,19 & 0,65 & - & 0,65 \\
\hline 17 & 17,65 & 82,35 & - & 57,84 & 7,84 & 7,84 & 21,57 & 12,75 & - & - & - & - \\
\hline 18 & 45,45 & 54,55 & - & 38,96 & 25,97 & 6,49 & 24,68 & 1,30 & 1,30 & 1,30 & - & - \\
\hline 19 & 22,73 & 77,27 & - & 31,06 & 13,64 & 7,58 & 11,36 & 2,27 & - & 3,79 & - & 30,30 \\
\hline 20 & 40,30 & 59,70 & 4,48 & 4,48 & 76,12 & - & - & - & 14,93 & - & - & - \\
\hline 21 & 54,00 & 46,00 & 0,67 & 29,33 & 68,00 & - & 1,33 & 0,67 & - & - & - & - \\
\hline 22 & 95,56 & 4,44 & 2,22 & 13,33 & 62,22 & - & - & 22,22 & - & - & - & - \\
\hline 23 & 84,91 & 15,09 & 5,66 & 20,75 & 62,26 & - & - & 9,43 & - & - & 1,89 & - \\
\hline 24 & 57,14 & 42,86 & - & 75,00 & 3,57 & - & 7,14 & 8,93 & - & 1,79 & 3,57 & - \\
\hline
\end{tabular}

* Матеріали та методи.

Полленохорична структура, підкреслює особливості запилення серед фітоценозів. Визначено, що у фітоценозах: діброви, луки (крім № 21 дослідженої ділянки), чорнокленові угруповання (крім № 24 досліджуваної ділянки) та діброва поблизу болота (крім № 16 досліджуваної ділянки), переважає ентомофільний тип опилення. У фітоценозах - насадження сосни (крім № 18 досліджуваної ділянки), псамофільний степ нижньої частини проміждюнного пониззя і верхньої частини дюн, а також діброва поблизу болота - переважає анемофільний тип опилення. Переважаючим типом запилення є анемофілія - запилення вітром. Поллехорична структура вказує на значну роль вітру в запилені фітоценозів.

Діаспорохорія відображає типи дисемінації - способи розселення діаспор рослин. Проведений аналіз дозволив встановити, що діаспорохорія серед рослин і рослинності досліджуваного полігону відбувається за багатьма типами. Можна виділити три головні типи: балісти, анемохори та епізоохори. Ці та інші типи розповсюдження переважають у таких досліджуваних фітоценозах: Anch - 75,00 \% чорнокленові ценози; $\mathrm{Bal}$ - 89,74 \% псамофільний степ, верхня частина дюн; Ach - 8,00 \% 
псамофільний степ, нижня частина проміждюнного пониззя; Bar - 8,72 \% чорнокленова діброва; Endz -51,47 \% псамофільний степ, верхня частина дюн; Hdch $14,93 \%$ діброва поблизу болота; Myrm - 8,72 \% чорнокленова діброва; Perv 14,71 \% псамофільний степ, верхня частина дюн; Synz - 30,30 \% в'язо-осокорова діброва. Різноманітні шляхи рознесення насіння призводять до формування значного потенціалу дистрибуції фітоценозів у межах та за межами дослідженого полігону.

Висновки. Екоморфічний аналіз дозволяє оцінити екологічну специфіку досліджених фітоценозів, що є основою для розробки екологічно обгрунтованого їх збереження.

Степанти і сільванти складають основну частину рослинного покриву. Використання екоморф О.Л. Бельгарда у фітоіндикаційних дослідженнях дозволяють встановити трофність едафотопу, водний режим або тип гігротопу у типології лісів. Найменша трофність едафотопу характерна для псамофільного степу (індекс 1,04), а найбільша - для в'язо-осокорової діброви (індекс 2,31). Найбільш сухі умови характерні для псамофільного степу (індекс 1,44), а найбільш вологі для діброви поблизу болота (індекс 4,19$)$ ). Луки, насадження сосни, чорнокленовні угруповання перебувають на одному рівні режиму вологості (вологі умови, сприятливі для ксеромезофітів).

У досліджуваних фітоценозах переважаючим типом запилення є анемофілія - запилення вітром. Поллехорична структура вказує на значну роль вітру в запилені фітоценозів. Діаспорохорія серед досліджуваних угрупованнь фітоценозів відбувається за допомогою трьох головних типів: Bal, Anch, Epz. Різноманітні шляхи рознесення насіння призводять до формування значного потенціалу дистрибуції рослин у межах та за межами досліджуваного полігону на арені р. Дніпро в межах природного заповідника «Дніпровсько-Орільський».

\section{Бібліографічні посилання}

1. Бельгард А. Л. Лесная растительность юго-востока УССР. Киев. 1950. 263 с.

2. Бельгард А. Л. Степное лесоведение. Москва. 1971. 336 С.

3. Воронов А. Г. Геоботаника. Москва. 1973. 384 с.

4. Ганжа Д. С. Флора осокорових лісів в умовах формування острівних екосистем середньої течії Дніпра в межах природного заповідника «Дніпровсько-Орільський» // Biсник Дніпропетр. держ. аграрно-економ. ун-ту. Вип. № 2 (56). 2015. С. 69-73.

5. Ганжа Д. С., Маховська К. $\boldsymbol{C}$. Екоморфічний аналіз флористичного складу піщаного степу арени Дніпра в межах природного заповідника «Дніпровсько-Орільський» // «Наукова весна 2016». Дніпропетровськ. 2016. С. 263-264.

6. Экоморфическая организация чернокленовников в псамофильной степи на арене р. Днепр / Д. С. Ганжа и др. // Питання степового лісознавства та лісової рекультивації земель. 2015. Вип. 44. С. 110-126.

7. Гудим Н. Г. Сезонна динаміка чисельності Pelobates fuscus на арені р. Дніпро (в межах природного заповідника «Дніпровсько-Орільський») // Питання біоіндикації та екології. Запоріжжя. 2015. Вип. 20. № 2. С. 130-141.

8. Гусев А. П. Фитоиндикаторы техногенного подтопления в зоне влияния полигона промышленных отходов // Вестник ВГУ. Серия: Геология. 2015. № 1. С. 122-127.

9. Иваныкина $\boldsymbol{T}$. В. Актуальность биоиндикации растений в условиях техногенного загрязнения // Вестник Амурского гос. ун-та. 2010. Вып. 51: Сер. Естеств. и Экон. науки. С. 81-83.

10. Корженевский В. В., Квитницкая $\boldsymbol{A}$. А. Фитоиндикация рельефообразования и опыт ее применения // Бюл. Никит. Бот. сада. 2011. Вып. 10. С. 5-28.

11. Лісовець О. І., Браӥлко В. А. Біолого-екологічна характеристика трав'яного покриву липо-ясеневої діброви центральної заплави р. Самара // Вісник Дніпропетр. ун-ту. Біологія. Екологія. 2011. Вип. 19. Т. 2. С. 93-102.

12. Матвеев Н. М. Оптимизация системы экоморф растений А. Л. Бельгарда в целях фитоиндикации экотопа и биотопа // Вісник Дніпропетр. ун-ту. Біологія. Екологія. 2003. Вип. 11. Т. 1. С. 105-113. 
13. Мелехова О. П., Егорова Е. И., Евсеева Т. И. и др. Биологический контроль окружающей среды: биоиндикация и биотестирование // Москва. 2007. 288 с.

14. Рахимов T. У. Фитоиндикация в оценке загрязнения окружающей среды // Наука и современность. 2012. Т. 16. № 1. С. 9-13.

15. Tарасов B. B. Флора Дніпропетровської і Запорізької областей // Дніпропетровськ. 2012. 296 с.

16. Шкаранда Ю. С., Корженевский В. В. Фитоиндикация экологической амплитуды популяции medicago marina l. на пересыпи о. Донузлав // Бюллетень ГНБС. 2015. Вып. 114. C. $13-19$.

17. Zhukov A., Zadorozhnaya G. Spatial heterogeneity of mechanical impedance of a typical chernozem: the ecological approach // Ekológia (Bratislava). 2016. Vol. 35. No. 3. P. 263.

Надійшла до редколегії 17.07.2016

Ю. Г. Приседський

Донещьький національний університет (м. Вінниия)

\title{
ВПЛИВ ЗАБРУДНЕННЯ СУЛЬФІТАМИ ТА ФТОРИДАМИ НА НАКОПИЧЕННЯ БІОМАСИ КВІТКОВИМИ РОСЛИНАМИ
}

Вивчено реакцію 7 видів квітково-декоративних рослин на забруднення грунту фторидами та сульфітами. Встановлено значну негативну дію забруднювачів на накопичення сирої та сухої маси усіма вивченими видами рослин. Найбільш стійкими за результатами дослідження виявилися кукіль звичайний (Agrostemma githago L.), космея жовтогаряча (Cosmos sulphureus Cav.), льон звичайний (Linum usitatissimum L.).

Ключові слова: декоративні рослини, механізми адаптації, стійкість.

\section{Ю. Г. Приседский}

\section{Донеикий наџиональный университет (2. Виннииа)}

\section{ВЛИЯНИЕ ЗАГРЯЗНЕНИЯ СУЛЬФИТАМИ И ФТОРИДАМИ НА НАКОПЛЕНИЕ БИОМАССЫ ЦВЕТОЧНЫМИ РАСТЕНИЯМИ}

Изучена реакция 7 видов цветочно-декоративных растений на загрязнение почвы фторидами и сульфитами. Установлено значительное негативное действие загрязнителей на накопление сырой и сухой массы изученными видами растений. Наиболее устойчивыми по результатам исследований являются куколь обыкновенный (Agrostemma githago L.), космея желтая (Cosmos sulphureus Cav.), лен обыкновенный (Linum usitatissimum L.).

Ключевые слова: декоративные растения, механизмы адаптации, устойчивость.

\author{
Ju. H. Pryesedeskyi \\ Donetsk National Univerity (m. Vinnitsa)
}

\section{THE IMPACT BY SULPHUR AND FLUORIDE ON THEACCUMULATION OF BIOMASS OFF ORNAMENTAL PLANTS}

Industrial soil pollution with heavy metals, sulphur, fluorine, chlorine, etc. has become important environmental factor that significantly affects plant organisms, causing their oppression. In this regard, we have studied the reaction of seven species of ornamental plants (Ageratum houstonianum cv. Bule Lagoon, Dahlia variabilis Desf., Echinacea purpurea L., Dahlia variabilis Desf., Calendula officinalis L., Cosmos sulphureus Cav.,

(C) Ю. Г. Приседський, 2016 